\title{
Lake Fluctuations, Plant Productivity, and Long-Term Variability in High- Elevation Tropical Andean Ecosystems
}

Author(s): Julieta Carilla , H. Ricardo Grau , Leonardo Paolini and Mariano Morales

Source: Arctic, Antarctic, and Alpine Research, 45(2):179-189. 2013.

Published By: Institute of Arctic and Alpine Research (INSTAAR), University of Colorado

DOI: http://dx.doi.org/10.1657/1938-4246-45.2.179

URL: http://www.bioone.org/doi/full/10.1657/1938-4246-45.2.179

BioOne (www.bioone.org) is a nonprofit, online aggregation of core research in the biological, ecological, and environmental sciences. BioOne provides a sustainable online platform for over 170 journals and books published by nonprofit societies, associations, museums, institutions, and presses.

Your use of this PDF, the BioOne Web site, and all posted and associated content indicates your acceptance of BioOne's Terms of Use, available at www.bioone.org/page/terms_of_use.

Usage of BioOne content is strictly limited to personal, educational, and non-commercial use. Commercial inquiries or rights and permissions requests should be directed to the individual publisher as copyright holder. 


\section{Lake Fluctuations, Plant Productivity, and Long-Term Variability in High-Elevation Tropical Andean Ecosystems}

\author{
Julieta Carilla $* \$ \S$ \\ H. Ricardo Grau* $\$$ \\ Leonardo Paolini*\$ and \\ Mariano Morales $\$$ \\ *Instituto de Ecología Regional, \\ Universidad Nacional de Tucumán, CC \\ 34, (4107) Yerba Buena, Tucumán, \\ Argentina \\ $\dagger$ Instituto Argentino de Nivología, \\ Glaciología y Ciencias Ambientales \\ (IANIGLA), CC 330, Av. Ruiz Leal s/n, \\ (5500) Mendoza, Argentina \\ †Corresponding author. \\ julietacarilla@gmail.com \\ $\S$ Consejo Nacional de Investigaciones \\ Científicas y Técnicas (CONICET)
}

\begin{abstract}
Environmental trends and ecosystems' ranges of variability are little known in tropical very high elevation Andean ecosystems (above $4400 \mathrm{~m}$ a.s.l.). We combined satellite image analyses and dendrochronological methods with instrumental records at lower elevation to assess changes in lake size and indices of plant productivity of subtropical high-elevation ecosystems in northern Argentina and southern Bolivia. Between 1985 and 2009, interannual lake fluctuations assessed with Landsat images were positively correlated with interannual variations in regional precipitation and de Martonne's aridity index, showing a decreasing trend in moisture availability during the period. Changes in lake size were positively correlated with radial growth of Polylepis tarapacana, and with MODIS-derived phenological parameters of enhanced vegetation index (EVI; an index of vegetation "greenness") between 2001 and 2010. This indicates that water balance has a significant effect on ecosystem functioning, which is related to regional scale atmospheric circulation. A long-term tree ring chronology (starting in 1750) showed that tree growth during recent decades was lower than the last 180 years, and were comparable to growth patterns that occurred between 1775 and 1825 . These results suggest that if recent climatic trends continue, long-term ranges of variability in ecosystem functioning could be exceeded.
\end{abstract}

\section{Introduction}

By being close to the physiological limits of plant growth, highelevation ecosystems are highly sensitive to climate change. For example, in subtropical mountains, water balance variability seems to play a key role in ecosystem functioning (Morales et al., 2004; Lupo et al., 2007). Quantifying the relationship between climate variability and plant productivity is essential to understand the functioning of these ecosystems and the potential consequences of future climate scenarios. Such quantitative analyses, however, are scarce due to the paucity of both instrumental climatic data and field-based ecological monitoring. Combination of multiscale tools, such as dendrochronology and greenness indices derived from satellite imagery, can help address these research gaps (Boninsegna et al., 2009).

In the southern tropical Andes $\left(15-30^{\circ} \mathrm{S}\right)$, high-elevation ecosystems are characterized by sparse vegetation with scattered woody species and wetlands (lakes and peatbogs) in depressed topographic locations. This part of the Andes represents one of the largest extensions of very high elevation ecosystems (above 4400 $\mathrm{m}$ a.s.1.) worldwide. In general, low-latitude Andes are expected to be severely affected by global warming, particularly at higher elevations (Vuille and Bradley, 2000; Vuille et al., 2003; Urrutia and Vuille, 2009). Related changes in precipitation patterns are also expected to have strong ecological effects, particularly in the southern tropical Andes, where plant growth is largely limited by rainfall (Morales et al., 2004; Soliz et al., 2009).

To understand the ecological effects of ongoing climate change, the analysis of recent trends needs to be combined with long-term records that provide historical or natural ranges of variability (Landres et al., 1999; Wong and Iverson, 2004). Due to the paucity of instrumental weather stations, there are no systematic assessments of trends in ecosystems' change in the southern tropical very high elevation Andean ecosystems. In this paper, we contribute to filling this gap by conducting an analysis of variability and trends in ecosystem functioning at different temporal scales, taking advantage of three newly available methodological tools for the area: (1) multidecadal, annual resolution analysis of lake fluctuations based on Landsat satellite images as an index of water balance; (2) 10-year changes in indices of plant productivity derived from Moderate Resolution Imaging Spectroradiometer (MODIS) satellite data at submonthly temporal resolution; and (3) a 258-year dendroecological analysis of annual tree ring widths of Polylepis tarapacana, the largest woody species of the area. The combination of these tools allowed us to produce the first analysis of interannual variability and recent trends of change in some components of high-elevation Andean ecosystems functioning in the context of climate change and historical ranges of variability.

The study area is characterized by a network of high-elevation shallow endorheic lakes in which water level fluctuates in response to climatic changes (Lupo et al., 2007) and can be measured with Landsat TM images available since the early 1980s (Caziani and Derlindati, 1999). Plant biomass and productivity are low and mainly concentrated in peatlands (Squeo et al., 2006; Baldassini et al., 2012). Seasonal-scale analysis of changes in vegetation indices provides a reliable estimator of plant gross productivity patterns (Moreau et al., 2003; Fraser et al., 2011). Due to the temporal resolution (e.g. two images per month), pixel size $(250 \mathrm{~m} \times 250 \mathrm{~m})$, and pre-processing level, MODIS satellite products are the best tool available to estimate monthly productivity changes for large areas during the last 10 years. The study of tree rings for ecological purposes (dendroecology) is a useful tool to assess trends in plant growth for decades to millennia (Schweingruber, 1996; D'arrigo et al., 2000; Wang et al., 2004; Srur 
et al., 2011). During the past decade, our group developed dendrochronological methods for tropical mountains, based on samples of the long living treelet $P$. tarapacana, which allow multi-century reconstructions of radial growth patterns and their relationship with climate variability (Argollo et al., 2004; Morales et al., 2004, 2012; Soliz et al., 2009). We hypothesized that inter-annual lake fluctuations are an indicator of water balance and ecosystem productivity that should also be reflected in tree radial growth.

By combining these methodological tools, we pursued the following three particular objectives. (1) To quantify interannual lake fluctuations between 1985 and 2009 and their association with instrumental climatic records. To reach this goal, we (a) described the trends in lake size during the last decades, and (b) assessed the potential use of lakes' size to estimate regional water budget. (2)
To analyze the association between lake variability and two indices of plant productivity using (a) Enhanced Vegetation Index (EVI) based on MODIS satellite images, and (b) tree ring widths of $P$. tarapacana. (3) To contextualize trends in ecosystems functioning derived from the previous objectives in relationship with long-term variability derived from a 258 -year tree ring width chronology.

\section{Methods}

\section{STUDY AREA}

The study was conducted in the extreme northwest of Argentina (Rinconada, Jujuy) and extreme southwest of Bolivia (Sud Lipez, Potosí), between $21^{\circ} 41^{\prime}-23^{\circ} 17^{\prime} \mathrm{S}$ and $65^{\circ} 10^{\prime}-67^{\circ} 26^{\prime} \mathrm{W}$ (Fig. 1). All the area is located above $4400 \mathrm{~m}$, and covers approximately



FIGURE 1. (A) Study area location in South America; (B) lakes (codes in capital letters, see Table 1), and dendrochronological sample sites used for the regional chronology (indicated with white dots); (C) geographical location of meteorological stations used for the analysis; and (D) Spearman correlation map between precipitation data from meteorological stations and the average of the differences of the six smaller lake sizes. 
$9300 \mathrm{~km}^{2}$, including ca. 30 lakes ranging in size from 1 to $40 \mathrm{~km}^{2}$. Vegetation is dominated by Festuca spp. grasslands, several small shrubby species (Parastrephia, Adesmia), and cushion plants (Azorella compacta). The only treelet species that occurs in the area, Polylepis tarapacana, can be as tall as $2.5 \mathrm{~m}$ (Kessler, 1995). The most productive areas in the landscape are the peatbogs or "vegas," wet zones dominated by cespitous Juncaceae and Cyperaceae, and Poaceae of the genus Deyeuxia.

There are no permanent human settlements, but temporary "puestos" serve as logistic bases for summer livestock grazing (llamas and sheep). Since the area represents important habitats for vertebrate species with high conservation value such as Andean flamingos (Phoenicoparrus jamesi, P. andinus), vicuñas (Vicugna vicugna), Andean rheas (Pterocnemia pennata), and high Andes wildcats (Leopardus pajeros, L. jacobitus), and there is an incipient tourist development, both the Argentinean and Bolivian sectors are under protected status: Reserva Provincial Altoandina de la Chinchilla in Argentina and Reserva Nacional Eduardo Avaroa in Bolivia.

\section{CLIMATE}

The study area (Fig. 1, part B) is cold and dry, with mean annual temperatures lower than $5{ }^{\circ} \mathrm{C}$ and an annual precipitation lower than $100 \mathrm{~mm}$ (http://www.worldclim.org). Precipitation over the southern tropical Andes is characterized by a marked seasonality. December to February precipitation accounts for $70-90 \%$ of the total annual precipitation (Garreaud et al., 2003; Vuille and Keimig, 2004). Across the Altiplano, precipitation decreases from 600-1000 $\mathrm{mm}$ in the northeastern Cordillera to less than $100 \mathrm{~mm}$ in the southwestern mountains adjacent to the Atacama Desert (Vuille et al., 2003; Vuille and Keimig, 2004).

Summer precipitation is related to local convection, which in turn is associated with variations in the mean zonal wind in the upper troposphere, and with an easterly zonal flow favoring wet conditions (Garreaud et al., 2003). Rainfall variability appears to be related to the position and intensity of the Bolivian High, an upper-level pressure cell that develops over the central Andes during summer due to the intense convection over the Amazon basin (Lenters and Cook, 1997). Wet episodes are related to a southward displacement of the Bolivian High, the consequent reduction in meridional baroclinicity at subtropical latitudes, and the weakening of the westerly flow over the central Andes promoting the ingression of wet air masses from the east (Garreaud and Aceituno, 2001; Vuille and Keimig, 2004).

Interannual changes in the mean zonal flow over the southern tropical Andes are modulated by sea surface temperatures (SST) over the tropical Pacific (Vuille et al., 2000; Garreaud and Aceituno, 2001; Bradley et al., 2003). Positive anomalies in SST over the tropical Pacific of the South American coast (El Niño events) are associated with an intensification of the westerly flow and below-average precipitation over the southern tropical Andes. In contrast, rainfall is more abundant during negative SST in the tropical Pacific (La Niña events), concurrent with enhanced easterly flow bringing humid air masses from the east over the region (Aceituno, 1988; Lenters and Cook, 1999; Vuille, 1999; Vuille et al., 2000; Garreaud et al., 2003).

Instrumental records from La Quiaca, the closest instrumental weather station, shows a slight increase in precipitation during the 20th century $\left(r^{2}=0.1, p<0.05\right)$ which has become more abrupt since $1970\left(r^{2}=0.4, p<0.001\right)$. However, La Quiaca is more than $1000 \mathrm{~m}$ lower in elevation than the study area, and $150 \mathrm{~km}$ east, thus is likely to be partially influenced by different general atmospheric circulation patterns. The same trend $\left(r^{2}=0.1, p<\right.$ 0.01 ) is evidenced in the average of 11 weather stations of the region during the common period (1903-2007).

\section{LAKE FLUCTUATIONS AND RELATIONSHIPS WITH REGIONAL CLIMATE}

To quantify interannual fluctuations in lake sizes (objective 1), we used Landsat TM images (30 m pixel resolution), path 232 and row 076 , from 1985 to 2009 . We selected nine lakes located between 4400 and $4600 \mathrm{~m}$ a.s.l. (Fig. 1, part B; Tables 1 and 2). To describe lake fluctuations we report area $\left(\mathrm{km}^{2}\right)$, relative size (annual area/maximum area during the period 1985-2009), and

TABLE 1

Lakes measured in this study (with codes, see Fig. 1); minimum and maximum lake sizes; coefficient of determination $\left(r^{2}\right)$; slope of size trend between 1985 and 2009; \% of total lake size change in relation to initial value (2009-1985 size); and Pearson's correlation ( $r$ ) with regional chronology ring width raw data.

\begin{tabular}{|c|c|c|c|c|c|}
\hline Lakes & Size range $\left(\mathrm{km}^{2}\right)$ & $r^{2}$ & $\begin{array}{l}\text { Regression slope } \\
\left(\text { B. } \mathrm{km}^{2} / \mathrm{yr}\right)\end{array}$ & $\begin{array}{l}\text { Decreasing size } \\
\text { in } 24 \mathrm{yrs}(\%)\end{array}$ & $\begin{array}{c}r \text { with regional } \\
\text { chronology (raw) }\end{array}$ \\
\hline Cerro Negro (CNE) & $0.06-2.45$ & $0.54 * * *$ & -0.07 & -85.84 & $0.53 * *$ \\
\hline del Morro (MOR) & $0.55-2.76$ & $0.83 * * *$ & -0.08 & -71.03 & $0.54 * *$ \\
\hline Isla Grande (IGr) & $0.0-3.07$ & $0.75^{* * *}$ & -0.10 & -100.00 & $0.56 * *$ \\
\hline Catal (CAT) & $0.74-3.10$ & $0.76 * * *$ & -0.07 & -67.19 & $0.50 *$ \\
\hline Polulos (POL) & $3.01-4.86$ & $0.39 * * *$ & -0.05 & -36.90 & $0.45^{*}$ \\
\hline Chojllas (CHO) & $5.08-6.00$ & $0.58 * * *$ & -0.03 & -9.49 & $0.44 *$ \\
\hline Palar (PAL) & $0.94-14.72$ & $0.38 * * *$ & -0.36 & -93.30 & 0.30 \\
\hline Coruto (COR) & $15.46-24.52$ & $0.14^{+}$ & -0.12 & -29.34 & 0.03 \\
\hline Vilama (VIL) & $18.29-35.18$ & $0.26^{* *}$ & -0.23 & -21.70 & 0.29 \\
\hline
\end{tabular}

*** $p<0.001, * * p<0.01,{ }^{*} p<0.05,{ }^{+} p=0.07$. 
TABLE 2

Pearson correlations between average of relative lake size for 1985-2009 period. For explanation of lake codes, see Table 1.

\begin{tabular}{|c|c|c|c|c|c|c|c|c|}
\hline Lakes & $\mathrm{CNE}$ & MOR & IGr & CAT & POL & $\mathrm{CHO}$ & PAL & $\mathrm{COR}$ \\
\hline MOR & $0.88 * * *$ & & & & & & & \\
\hline $\mathrm{IGr}$ & $0.89 * * *$ & $0.93 * * *$ & & & & & & \\
\hline CAT & $0.79 * * *$ & $0.95^{* * *}$ & $0.93 * * *$ & & & & & \\
\hline POL & $0.84 * * *$ & $0.76 * * *$ & $0.82 * * *$ & $0.76 * * *$ & & & & \\
\hline $\mathrm{CHO}$ & $0.51 * *$ & $0.73 * * *$ & $0.71 * * *$ & $0.78 * * *$ & $0.52 * *$ & & & \\
\hline PAL & $0.86 * * *$ & $0.77 * * *$ & $0.76 * * *$ & $0.73 * * *$ & $0.84 * * *$ & $0.45^{*}$ & & \\
\hline COR & 0.38 & 0.34 & 0.39 & $0.41 *$ & $0.41^{*}$ & $0.53 * *$ & $0.52 * *$ & \\
\hline VIL & $0.65^{* * *}$ & $0.60 * *$ & $0.54 * *$ & $0.59 * *$ & $0.55^{* *}$ & $0.57 * *$ & $0.69 * * *$ & $0.81 * * *$ \\
\hline
\end{tabular}

$* * * p<0.001, * * p<0.01, * p<0.05$. Probability values are independent for each variable (i.e. there is no correction for multiple comparisons).

area differences between two consecutive years relative to the initial area $\left(\left[\mathrm{A}_{\mathrm{x}}-\mathrm{A}_{\mathrm{x}-1}\right] / \mathrm{A}_{\mathrm{x}-1}\right)$. To determine the area of the lake in each particular image, we classified images using the non-parametric method Support Vector Machine (SVM; Hsu et al., 2007; see online Appendix).

We assigned one size data for each of the 24 years between 1985 and 2009, the only exception being 1986 for which there was no good quality image available. For years during which we had more than one good quality available image, we used the average of the different lake size measures. Available images for each year varied with regard to their acquisition date, but we found that intra-annual variation was on the order of $15 \%$ of relative range in comparison to more than $100 \%$ of interannual variation, so we assumed that the seasonal variation was negligible. To further validate this assumption, intra-annual fluctuation was not significantly different (repeated measures ANOVA: $\left.F_{(2,90)}=2.21 ; p=0.11\right)$ between lake size measures of different months. Dates of images used for this analysis are reported in the online Appendix.
To assess the relationship between instrumental records of precipitation variability and changes in lake size (objective 1), we compiled the available high-altitude precipitation records from meteorological stations relatively close to our study area or at similar elevation although located as far as $300 \mathrm{~km}$ north (Fig. 1, part C). Monthly precipitation records were obtained from the Servicio Meteorológico Nacional in Argentina (SMN), the Servicio Nacional de Meteorología e Hidrología in Bolivia (SENAMHI), and the Dirección General de Aguas in Chile (DGA). The 11 weather stations used are located between $17^{\circ} \mathrm{S}$ and $22^{\circ} \mathrm{S}$, and between 3500 and $4600 \mathrm{~m}$ a.s.l. (Fig. 1, part C; Table 3). We combined the 11 records into one regional precipitation record. To avoid overweighting weather stations with higher rainfall on the regional mean, each precipitation record was standardized ([year value - interval average]/standard deviation) with respect to the common interval 1983-2000 period, and then precipitation anomalies were averaged. We considered a 12-month cycle of lake size and considered annual precipitation from August to July which is more consistent with biological cycles in the region than the calendar year.

TABLE 3

Spearman correlation between interannual differences in average annual lake size and interannual variations in precipitation records $(R)$ for 11 meteorological stations located along Bolivian and Chilean Altiplano (see Fig. 1, part D, for specific locations), regional precipitation average (R), and de Martonne's Aridity Index (AI, performed for La Quiaca weather station). Countries codes: Bo-Bolivia, Ch-Chile, Ar-Argentina. For explanation of lake codes, see Table 1.

\begin{tabular}{|c|c|c|c|c|c|c|c|c|c|}
\hline Stations, country & $\begin{array}{l}\text { Altitude } \\
\text { (m a.s.1.) }\end{array}$ & Period & $\mathrm{CNE}$ & MOR & $\mathrm{IGr}$ & CAT & POL & PAL & VIL \\
\hline (R) Colcha, Bo & 3690 & 1980-2000 & $0.52 *$ & $0.68 * *$ & $0.70 * *$ & $0.66 * *$ & 0.40 & 0.33 & 0.19 \\
\hline (R) Oruro, Bo & 3706 & $1943-2009$ & $0.52 *$ & $0.50 *$ & $0.52 *$ & 0.23 & 0.22 & 0.20 & 0.27 \\
\hline (R) Uyuni, Bo & 3765 & $1975-2003$ & 0.38 & $0.58 *$ & $0.49 *$ & $0.59 *$ & 0.41 & 0.22 & 0.43 \\
\hline (R) Cancosa, Ch & 4280 & $1977-2007$ & $0.62 * *$ & $0.46^{* *}$ & $0.69 * *$ & $0.58 *$ & $0.57 *$ & $0.48 *$ & $0.48^{*}$ \\
\hline (R) Chucuyo, $\mathrm{Ch}$ & 4300 & $1961-2006$ & $0.53 *$ & $0.46^{*}$ & $0.49 *$ & 0.33 & $0.46^{*}$ & 0.35 & $0.44 *$ \\
\hline (R) Chungara, Ch & 4570 & $1962-2008$ & 0.39 & $0.48 *$ & 0.38 & 0.35 & 0.33 & 0.25 & 0.28 \\
\hline (R) Colchane, $\mathrm{Ch}$ & 3720 & 1978-2007 & $0.50 *$ & $0.61 * *$ & $0.57 * *$ & $0.53 *$ & $0.42 *$ & 0.27 & 0.24 \\
\hline (R) Cotakotani, Ch & 4350 & 1979-2003 & $0.41^{+}$ & $0.56^{*}$ & $0.44 *$ & $0.49 *$ & 0.32 & 0.33 & $0.42^{+}$ \\
\hline (R) L. Pampa, Ch & 4200 & 1982-2007 & $0.56^{* *}$ & $0.55^{* *}$ & $0.58 * *$ & $0.53 * *$ & $0.56 * *$ & $0.45^{*}$ & 0.39 \\
\hline (R) Putre, Ch & 3500 & 1970-2007 & 0.37 & $0.51 *$ & $0.45^{*}$ & 0.37 & $0.41^{+}$ & 0.33 & 0.27 \\
\hline (R) La Quiaca, Ar & 3440 & $1903-2000$ & $0.55 *$ & 0.45 & 0.47 & $0.57 *$ & 0.36 & 0.34 & 0.35 \\
\hline (AI) La Quiaca, Ar & & $1903-2000$ & $0.55^{*}$ & $0.45^{+}$ & $0.47^{+}$ & $0.57 *$ & 0.36 & 0.34 & 0.35 \\
\hline Precipitation average & & 1903-2009 & $0.60 *$ & $0.48^{* *}$ & $0.67 * *$ & $0.55 * *$ & $0.50 * *$ & $0.41^{+}$ & $0.47 *$ \\
\hline
\end{tabular}

$* * p<0.01 * p<0.05{ }^{+} p \leq 0.07$. Probability values are independent for each variable (i.e. there is no correction for multiple comparisons). 
To assess the relationship between lake levels and water balance, we calculated de Martonne's aridity index, defined as precipitation $(\mathrm{mm}) /$ temperature $\left({ }^{\circ} \mathrm{C}\right)+10($ de Martonne, 1926). This aridity index, based on precipitation and temperature records, was only calculated for La Quiaca weather station (ca. $150 \mathrm{~km}$ to the east, at $1000 \mathrm{~m}$ lower elevation), the only one with a reliable long-term temperature record. We also assessed the relationship between $\mathrm{La}$ Quiaca temperature and changes in lake size.

\section{SATELLITE-DERIVED INDICES OF PLANT PRODUCTIVITY}

We used Moderate Resolution Imaging Spectroradiometer (MODIS) images from 2000 to 2010, georeferenced and reprojected to UTM 19 south (DATUM WGS84), in order to describe temporal patterns of vegetation productivity using EVI (enhanced vegetation index; Huete et al., 2002). These patterns were based on a 16-day composite ( 23 images/yr) of $250 \times 250 \mathrm{~m}$ spatial resolution with rescaled values ranging from 0 to 1 . EVI enhances the vegetation signal with improved sensitivity through a decoupling of the background signal and a reduction of atmosphere influences (Huete et al., 2002). EVI temporal series obtained from MODIS were analyzed using TIMESAT software (Jönsson and Eklundh, 2004), which quantifies phenological signals found in temporal series of satellite image data. TIMESAT adjusts local functions for each temporal series point and combines these functions in a model of phenological patterns. Based on these functions, TIMESAT provides statistical descriptors of the seasonal pattern of the analyzed variable (EVI in this case) through the year. For this study, we selected four phenological variables calculated the following for the $9300 \mathrm{~km}^{2}$ study area (Fig. A1 in online Appendix). (1) Growing season duration (GS; in days between GS starting and ending). For the first year in the series, GS starts in mid-2000, and ends in mid-2001. (2) Maximum EVI value (MV). (3) Growing season amplitude (AMP, the difference between MV and base value of EVI that is the average of the EVI minimum values; beginning and ending of GS). (4) Seasonal total integral (TI), an index of absorbed photosynthetically active energy accumulated in one growing season (Running et al., 2004).

To explore associations between lake fluctuations and plant productivity (objective 2a), we used Pearson's correlation coefficients.

\section{DENDROCHRONOLOGICAL ANALYSIS OF POLYLEPIS TARAPACANA}

In this study, three tree-ring chronologies from $P$. tarapacana were developed by incorporating two new chronologies from Ramada and Cerro Negro sites as well as updating and extending back in time the previously published chronology from Granada Volcano (1659-1999) (Morales et al., 2004) (Fig. 1, part A; Table A1 in online Appendix). All three sites are in the study area, between 4400 and $4800 \mathrm{~m}$ a.s.1., and share similar climatic characteristics (Fig. 1). Cross sections were chainsaw extracted from branches of living and dead trees, which remain well preserved for several centuries due to the dry and cold climate. Samples were processed following standard dendrochronological techniques (Stokes and Smiley, 1968). For dating purposes, we followed Schulman's con- vention (1956), which assigns to each tree ring the date of the year in which radial growth started. Annual rings were measured under a binocular stereoscopic microscope with a Bannister dendrometer measuring machine $(0.001 \mathrm{~mm}$ precision) connected to a computer (Robinson and Evans, 1980). The quality of the tree-ring chronology was tested by mean sensitivity (MS), mean correlation between series (RBAR), and expected population signal (EPS) statistics (described in online Appendix) generated by the computer program COFECHA (Holmes, 1983). Chronology statistics ranges met generally accepted reliability standards; mean intercorrelations: 0.51-0.57; MS: 0.26-0.31; RBAR: 0.26-0.32; and mean EPS: 0.71-0.87 (Morales et al., 2012).

The three $P$. tarapacana ring-width chronologies showed a similar interannual growth pattern across the study area, which allowed composition of a regional tree-ring chronology, merging in a single record the 93 tree-ring series from the three sites. A relative high series intercorrelation $(r=0.56)$ indicates the strong internal coherence between the three site chronologies (Morales et al., 2012) computed over the common period 1850-1999 (>6 samples in each site).

The ring-width measurements of the regional chronology were standardized to conserve the low frequency signal and to remove components of the variability likely not related to climate. Details on standardization methods and the statistics of the tree-ring chronologies are given in the online Appendix. The resulting regional standardized tree-ring chronology as well as the raw chronology (non-standardized ring width measurements) were used to explore correlations with lake size and with productivity index fluctuations during the recent past (objective 2) in order to evaluate the potential of $P$. tarapacana growth as a proxy of both factors. In addition, the 258-yr chronology was used to contextualize recent ecosystems changes into long-term ranges of variability (objective 3 ).

In general, when normality and homoscedasticity assumptions were not met we used non-parametric Spearman correlation. We report independent " $p$ " values for each pair of variables analyzed without adjusting for multiple comparisons (e.g. Bonferroni correction) or spatial autocorrelations. Although we acknowledge this fails to meet assumptions of statistical independence and degrees of freedom, we preferred it to provide readers with more transparent quantitative information for each independent analysis.

\section{Results}

\section{LAKE SIZE FLUCTUATIONS AND RELATIONSHIP WITH INSTRUMENTAL RECORDS}

Interannual size fluctuations of all lakes for the entire study area were highly positively correlated, suggesting a strong regional climatic control. Only Coruto lake (Bolivia) showed comparatively low correlation with some Argentinean lakes (between 0.3 and 0.4), and 22 cross-correlations were larger than 0.6 (Table 2). Lake sizes showed a negative trend between 1985 and 2009 (Fig. 2, parts A-C; Table 1), suggesting consistently drying conditions. Particularly dry years include 1996, 2004, 2007, 2008, and 2009. In 1996 lakes consistently decreased in size; Cerro Negro lake shrank to $2.4 \%$ of its maximum size, and in 2009 five lakes showed a significant decrease in size, with Isla Grande lake becoming completely dry. In contrast, in 1987 six of the nine lakes recorded their maxi- 


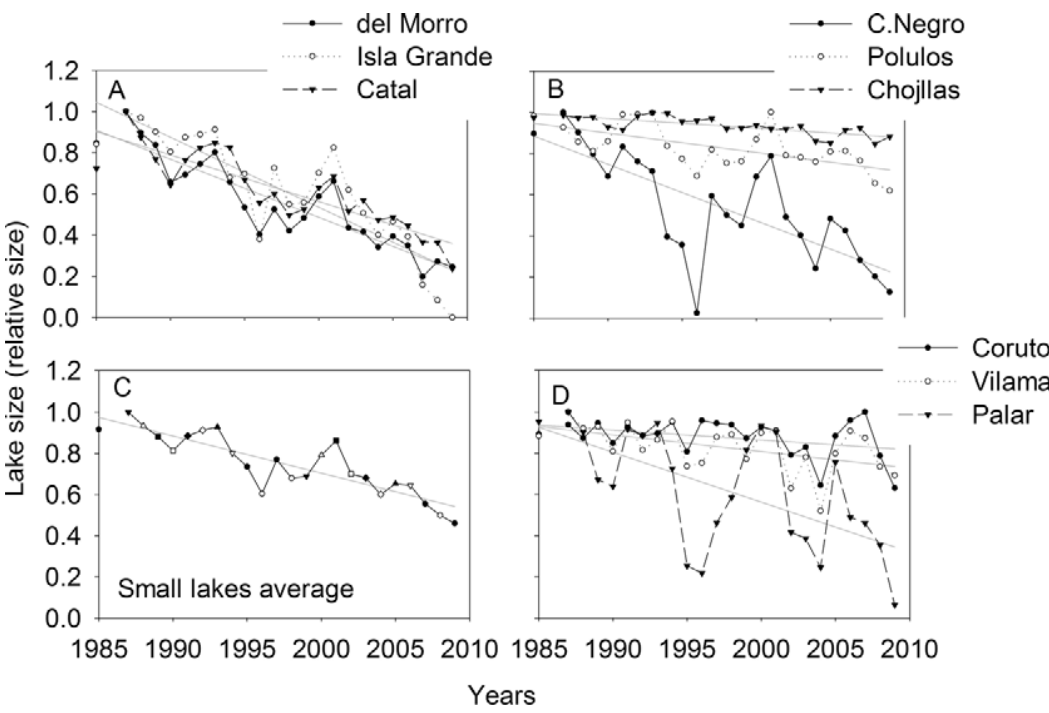

FIGURE 2. Trends in lake size, relative to maximum, for the 1985-2009 period. (A, B) Different groups of smaller lakes, (C) average of the six smaller lakes, and (D) larger lakes. Gray lines represent the linear regression. mumsize. The larger lakes, Vilama and Coruto, also showed a decreasing trend (Fig. 2, part D), but since the interannual fluctuations were higher (variances of 15.7 and $5.1 \mathrm{~km}^{2}$, respectively), the correlation coefficients were significantly lower (Table 1).

Fluctuations in lake size were correlated with the instrumental precipitation records from 11 high-elevation weather stations, and with de Martonne's aridity index calculated from La Quiaca instrumental records; values of Spearman's correlation coefficient ranged between 0.34 and 0.7 (Table 3). In particular, strong correlations were found between the annual differences in the mean of the six smaller lakes size and interannual variations in precipitation of the previous hydrological year, with higher coefficients $(0.51-0.66)$ in stations closer to the study area. Weather stations located below $4000 \mathrm{~m}$ a.s.l. presented weaker correlations with lakes than stations above this elevation (Fig. 1, part D; Table 3). With only two exceptions, Chojllas and Coruto, lake sizes were correlated with the regional average rainfall of the 11 weather stations with $r$ values of 0.41-0.60 (Table 3). The different lakes were correlated with de Martonne's aridity index with $r$ values between 0.34 and 0.57 (Table 3). The joint fluctuation of the differences in the nine lakes was correlated with precipitation of all meteorological records, with regional precipitation, and with de Martonne's aridity index of La Quiaca (Fig. 3, parts A and B). Lake size fluctuations were also negatively correlated with La Quiaca temperatures of the previous year (for six lakes with $r^{2}$ ranging from 0.14 to 0.38 , and the average of the six smaller lakes; Fig. 3, part C) and of the current year (for eight lakes with $r^{2}$ ranging from 0.16 to 0.32 , and the average of the nine lakes, $r^{2}=0.33, p=0.003$ ).

\section{LAKES AND VEGETATION PRODUCTIVITY PATTERNS}

Between 2000 and 2010, TIMESAT output for mean value (MV) and amplitude (AMP) was lowest in 2008 and highest in 2000 (Fig. 4, part A). Total integral (TI) presented the lowest values in 2000 and the highest in 2002, and GS duration ranged from 188.4 days (in 2000) to 229.8 days (in 2002) (Fig. 4, part B). The four EVI variables showed a decreasing trend in the 10 years of analysis. The decreases in MV and AMP were consistent throughout the period, while the TI and GS durations were not as a consequence of very low values in the first year of the series.

Fluctuations in the size of the six smallest lakes were associated with EVI variables; in particular, average size of the six smaller lakes were positively associated to MV (Fig. 4, part C) and with AMP (Fig. 4, part D) of the current and previous years $\left(r^{2}=0.89\right.$ and 0.85 , respectively; $p<0.01$ ). Instead, Vilama, Coruto (the two largest lakes), and Chojllas lakes were not significantly related to variables of EVI seasonality. Regional precipitation was correlated to $\mathrm{MV}\left(r^{2}=0.75, p<0.01\right)$ and to AMP $\left(r^{2}=0.56, p<0.05\right)$ of the current year, and to the aridity index (MV: $r^{2}=0.73, p<$ 0.01; and AMP: $r^{2}=0.60, p<0.05$ ).

Between 1985 and 2008, average annual lake size significantly correlated with $P$. tarapacana annual radial growth. Regional raw tree ring width chronology presented correlation coefficients higher than 0.44 with the size of the six smaller lakes (Table 1) and with the average sizes of these lakes (Fig. 5, part A), as both variables showed a decreasing trend during the last decades. The standardized tree ring chronology was correlated with interannual differences in the average lake sizes (Fig. 5, part B). Despite the short period with common data ( $n=10$ years), tree radial growth (raw and standard chronologies) also showed positive correlations with TI $(r=0.7, p<0.05$; Fig. 5 , part C) and GS duration $(r=0.64$, $p=0.06)$ of the current year.

\section{ECOSYSTEM PATTERNS AND LONG-TERM VARIABILITY}

A record of 258 years of growth variability was provided by the regional $P$. tarapacana ring width chronology (Fig. 6). This chronology covers the period 1553-2008, and a reliable number of tree ring series $(N>15$ trees) have been recorded since 1750 . The regional chronology showed a clear pattern of below-average growth during the first 70 years (1750-1820), followed by a peak of above-average growth between 1825 and 1850. A second period of relatively high growth occurred between 1945 and 1960, followed by a decrease during the last five decades of the series 

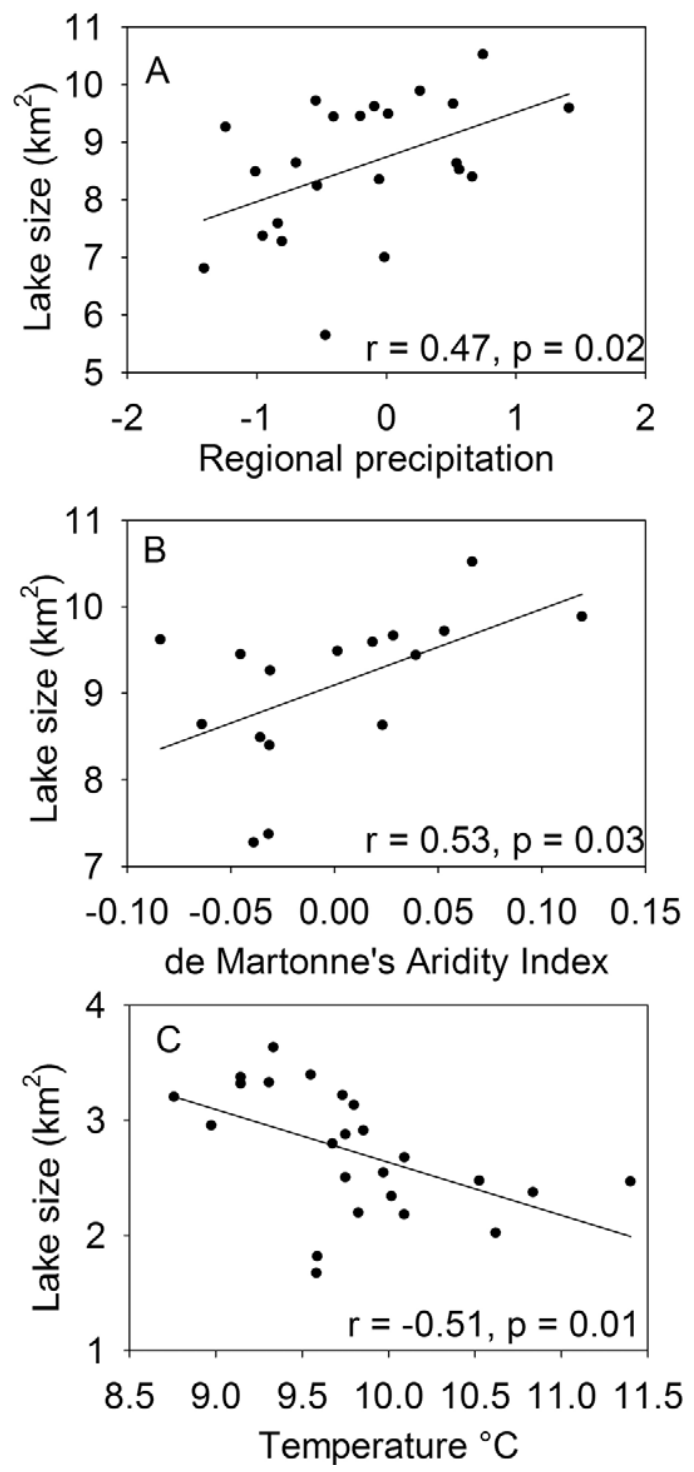

FIGURE 3. Relationship between lake size and meteorological data of the previous year. (A) Regional precipitation (averaged anomalies from the 11 meteorological stations with respect to the common period 1985-2009), (B) de Martonne's Aridity Index (based on La Quiaca station, 1985-2001 period) (size average of all lakes), and (C) mean temperature of La Quiaca (size average of the six smaller lakes).
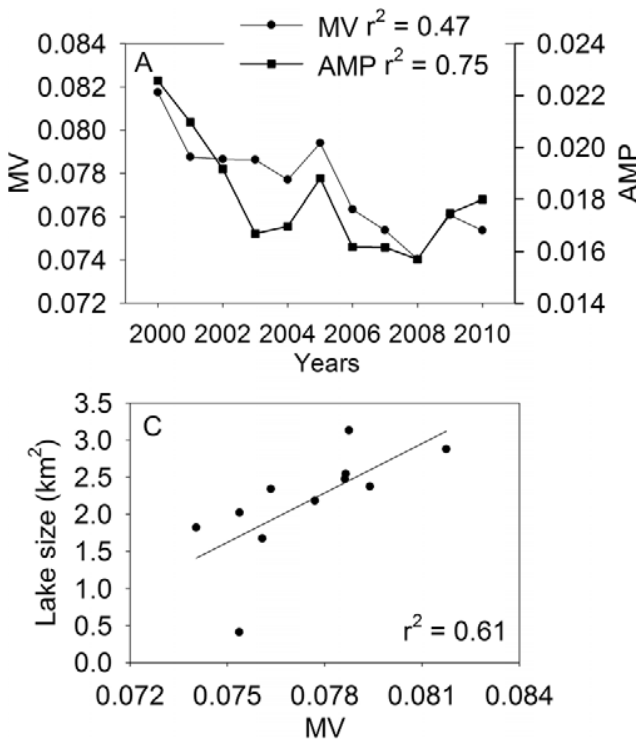
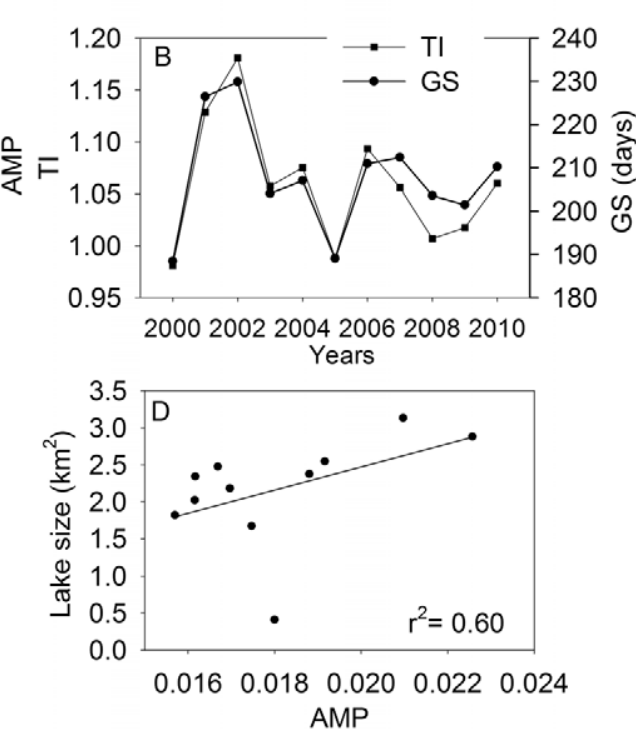

FIGURE 4. Temporal trends of TI MESAT parameters derived from the enhanced vegetation index (EVI) product from MODIS; (A) mean value (MV) and amplitude (AMP) ( $p$ $<0.05$ ), and (B) total integral (TI) and growing season (GS) duration. Relationship between lake sizes (average of the six smaller lakes) and (C) MV and (D) AMP for the 2000-2009 period $(p<0.01)$. 

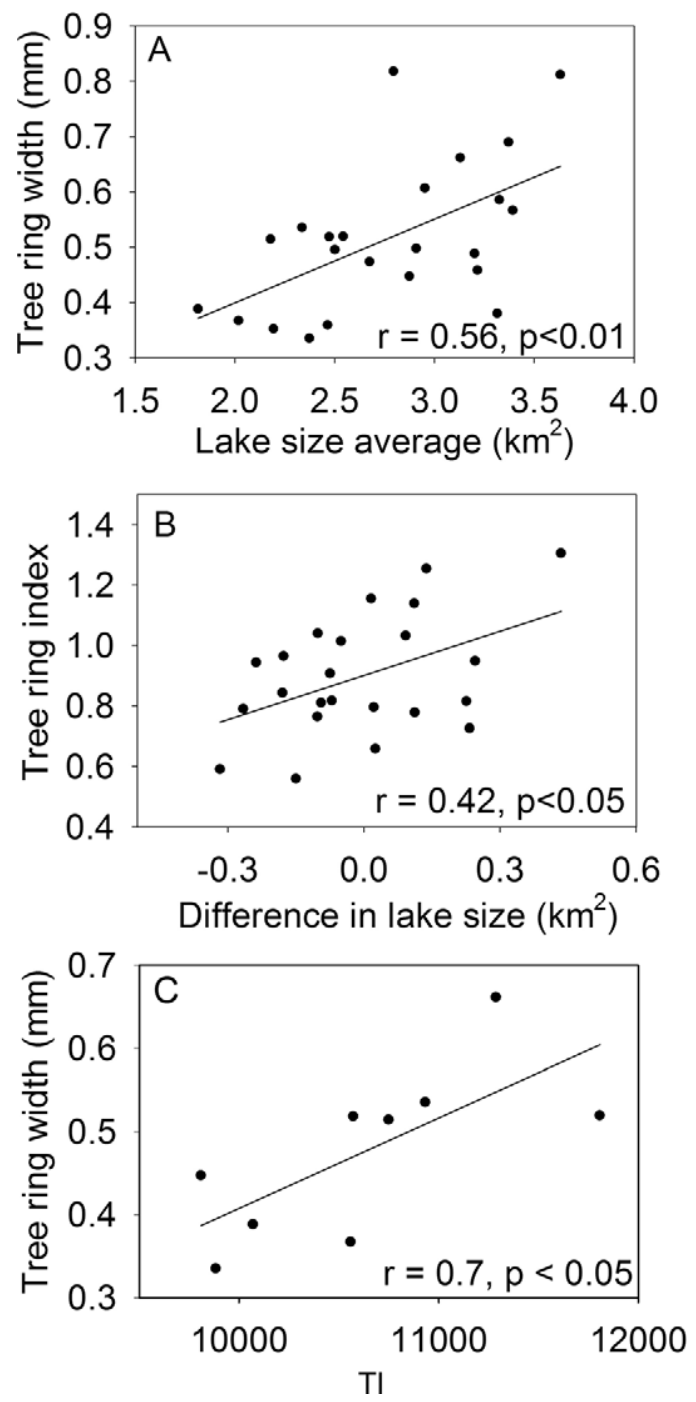

FIGURE 5. Relationship between $P$. tarapacana radial growth and indices of ecosystem function. (A) raw tree ring chronology vs. average lake size, (B) standardized tree ring chronology vs. differences in average of six smaller lakes sizes, and (C) raw tree ring chronology vs. EVI total integral.

(1960-2008). Multidecadal decreasing trend in radial growth of $P$. tarapacana during the last decades is coincident with lake area reductions and decreasing water balance reflected in lake size. According to the tree ring chronology, these relative low-growth conditions associated with a dry environment with low productivity in the current period have not occurred in the area since 1825, and are becoming similar to the $1750-1825$ period.

\section{Discussion}

The main contribution of this study was the combination of different methodological approaches in a multiscale analysis of functional trends of one of the ecosystems at the highest elevation globally, characterized by the paucity of climatic instrumental data and field-based ecosystem monitoring.
First (objective 1), we quantified interannual lake fluctuations and related them with instrumental climatic records in the southern tropical Andes. Consistent with our hypothesis, we found that changes in lake size measured with Landsat images are a good indicator of precipitation and water balance reflected in the de Martonne's aridity index. In particular, relatively smaller lakes (in the range between 1 and $6 \mathrm{~km}^{2}$ ) appear to track water balances more closely (Table 3), showing a common fluctuation pattern (Table 2). In contrast, larger lakes experienced higher interannual variability and less coherent pattern among them; which could be associated with lower area-depth ratio (Caziani and Derlindati, 1999) as well as larger and more complex watersheds. The strong correlation between lake size and instrumental records from meteorological stations located in northern Chile and Bolivia's Andes suggests that the hydrological pattern in the study area reflects the Altiplano regional climatic pattern, which, in turn, is associated with the Bolivian High (Vuille, 1999; Garreaud, 1999) as control of moisture transporting from the Amazon basin.

Second, interannual lake size fluctuations are coherent with interannual variations in ecosystem productivity. Lake size fluctuations were associated with vegetation productivity indices, such as phenological patterns of MODIS-derived EVI (objective 2a; Fig. 4, parts C and D) and Polylepis tarapacana radial growth (objective 2b; Fig. 5, parts A and B). The negative trend in small lake size during the last 25 years was accompanied with decreases in vegetation productivity inferred by EVI and $P$. tarapacana ring width, which were also associated with each other (Fig. 5, part C). Similar associations between tree radial growth and NDVI (vegetation index closely related to EVI) were found in other ecosystems such as temperate shrublands (Srur et al., 2011) and subtropical cloud forest (Ferrero, 2011). Despite the usefulness of EVI variables to determine ecosystem productivity, atmospheric conditions could lead to erroneous interpretations of these data. For example, the low value of TI (an index of accumulated annual gross productivity) and GS duration recorded in year 2000 resulted in the lack of a statistically significant decreasing trend between 2000 and 2010, but such a trend was clear between 2001 and 2010. Year 2000 was the wettest year in the last three decades (considering historical regional precipitation mean) and consequently was highly cloudy, which may have affected data on vegetation reflectance and EVI (Tan et al., 2011).

Third, tree ring chronologies captured hydrological balance, as reflected in the positive correlation between lake size and radial growth (Fig. 5, parts A and B) and the fact that both variables were correlated with instrumental data of the previous year. Our results support previous observations about the positive relationship between $P$. tarapacana radial growth and rainfall of the previous growing season to the tree ring formation (Argollo et al., 2004; Morales et al., 2004; Soliz et al., 2009). The same pattern is also reflected in lake level fluctuations where size variation depends on precipitations from the previously rainy season.

The response of trees and lakes to climatological patterns can also be evidenced by its association with ENSO (El Niño-Southern Oscillation) (Trenberth, 1997), one of the most important drivers of interannual variability in the world (Trenberth and Caron, 2000; Li et al., 2011). Consistent with Christie et al. (2009), our results showed an increase in tree radial growth during the ENSO events (Fig. A2 in the online Appendix). However, we also found that the 


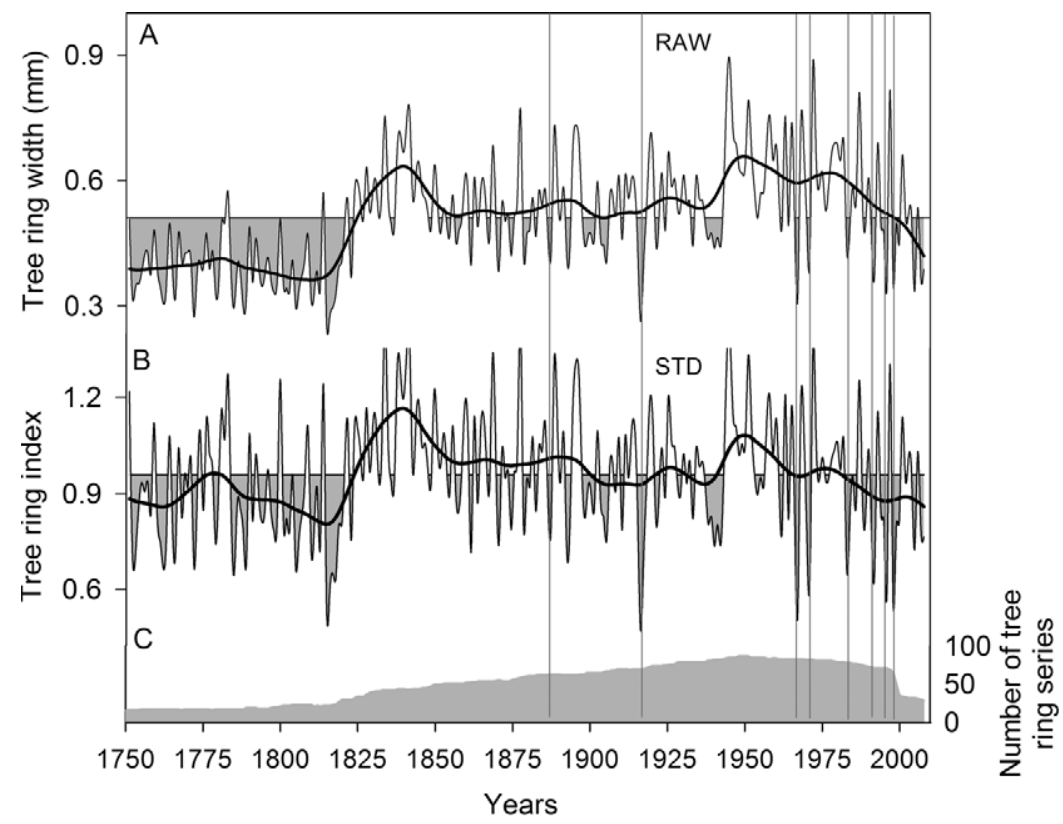

FIGURE 6. Regional chronology of Polylepis tarapacana (A) raw, and (B) standardized data, and (C) number of tree ring series (i.e. individual trees). Dark horizontal line indicates an adjusted curve of a $25-\mathrm{yr}$ smoothing cubic spline to emphasize the low frequency variations. Vertical gray lines indicate years of growth reduction (one and two years after the occurrence of El Niño-Southern Oscillation [ENSO] events). eight most severe $P$. tarapacana growth reductions in the last 258 years occurred in 1878, 1916, 1967, 1971, 1983, 1992, 1996, and 1998, one and two years after the occurrence of ENSO events. These results showed the complexity of the tree growth response to precipitation and temperature that was assessed in previous studies by Morales et al. (2004, 2012), Christie et al. (2009), and Soliz et al. (2009). Detailed analyses to explore the tree growth-ENSO relationship are developed in the online Appendix (Figs. A2 and A3). Relationship between ENSO and lake fluctuations was not clear during the analyzed period (1985-2009) during which 11 ENSO events occurred. A lake level reduction was recorded during the strong 1997-1998 ENSO event, which caused a strong drought in NW Argentina with negative impacts on socioeconomic activities (Gil Montero and Villalba, 2005).

Fourth, the decreasing trend in $P$. tarapacana ring width chronology during the last 50-60 years (Fig. 6) is consistent with the decreasing trend in smaller lake levels (Fig. 2) and decreasing values in EVI variables (Fig. 4, parts A and B). These quantitative associations between lake variability and vegetation productivity indices allowed us to contextualize recent trends in relation to longterm ranges of variability based in the development of a 258-year tree ring chronology (objective 3). Most remarkable is that the negative long-term trend in tree growth during the last 50 years identified by a 25-year spline (Fig. 6) highlights the sustained growth reduction since 1960 to the present in a centennial-scale context. This pattern is consistent with an extreme reduction of the Altiplano tree-ring-based precipitation reconstruction during the last three decades (Morales et al., 2012). Drier conditions were also identified in an aridity reconstruction for the central Andes region from southern South America (Boucher et al., 2011). Consistently, a sustained shrinking of small glaciers from the tropical Andes have been recorded since the second half of the 20th century (Ramirez et al., 2001; Francou et al., 2003; Vuille et al., 2008), which was associated with the increasing trend in temperature for the last decades across the region (Vuille and Bradley, 2000, Urrutia and Vuille, 2009).

In summary, results show a clear association between regional climatic patterns, lake fluctuations, and terrestrial ecosystems productivity. The three variables here quantified, lake size, $P$. tarapacana radial growth, and EVI values, reflect environmental changes and are related to interannual regional climate variability. The longterm record provided by dendrochronological analysis showed that plant productivity of the last decades is the lowest in the last 180 years, reaching values as low as those for several decades prior to 1820. If the aridization trends observed in recent decades continue, long-term ranges of ecological variability in the area could be exceeded. The combinations of dendrochronological methods with remote sensing assessments of lakes and vegetation phenology proved a useful approach to explore environmental trends in very high elevation Andean ecosystems.

\section{Acknowledgments}

This study was funded by grants from the National Geographic Society (Research and Exploration grant 8681-09), Argentine Research Council (CONICET-PIP 0968), and the Argentinean Agency for Promotion of Science (PICT 07-246). Alberto Ripalta, Ezequiel Aráoz, and Elvira Casagranda helped with field data collection, and Patricia Asesor helped with sample processing.

\section{References Cited}

Aceituno, P., 1988: On the functioning of the Southern Oscillation in the South American sector. Part I: surface climate. Monthly Weather Review, 116: 505-524.

Argollo, J., Soliz, C., and Villalba, R., 2004: Potencialidad dendrocronológica de Polylepis tarapacana en los Andes Centrales de Bolivia. Ecología en Bolivia, 39: 5-24. 
Baldassini, P., Volante, J. N., Califano, L. M., and Paruelo, J., 2012: Caracterización regional de la estructura y la productividad de la Puna mediante uso de imágenes Modis. Ecología Austral, 22: 2-32.

Boninsegna, J. A., Argollo, J., Aravena., J. C., Barichivich, J., Christie, D., Ferrero, M. E., Lara, A., Le Quesne, C., Luckman, B. H., Masiokas, M., Morales, M., Oliveira, J. M., Roig, F., Srur, A., and Villalba, R., 2009: Dendroclimatological reconstructions in South America: a review. Palaeogeography, Palaeoclimatology, Palaeoecology, 281: 210-228.

Boucher, E., Guiot, J., and Chapron, E., 2011: A millennial multi-proxy reconstruction of summer PDSI for southern South America. Climate of the Past, 7: 957-974.

Bradley, R. S., Vuille, M., Hardy, D., and Thompson, L. G., 2003: Low latitude ice cores record Pacific sea surface temperatures. Geophysical Research Letters, 30: 1174, http://dx.doi.org/10.1029/ 2002 GL016546.

Caziani, S., and Derlindati, E., 1999: Humedales altoandinos del noroeste de Argentina. Su contribución a la biodiversidad regional In Malvárez, I. (ed.), Tópicos Sobre Humedales Subtropicales y Templados de Sudamérica. Montevideo: Uruguay: ORCYT, 1-13.

Christie, D. A., Lara, A., Barichivich, J., Villalba, R., Morales, M. S., and Cuq, E., 2009: El Niño-Southern Oscillation signal in the world's highest-elevation tree-ring chronologies from the Altiplano, central Andes. Palaeogeography, Palaeoclimatology, Palaeoecology, 281: 309-319.

D’Arrigo, R. D., Malmstrom, C. M., Jacoby, G. C., Los, S. O., and Bunker, D. E., 2000: Correlation between maximum latewood density of annual tree rings and NDVI based estimates of forest productivity. International Journal of Remote Sensing, 21: 2329-2336.

De Martonne, E., 1926: Une nouvelle fonction climatologique: L'indice d'aridité. La Meteorologie, 2: 449-458.

Ferrero, M. E., 2011: Cambios en el crecimiento leñoso de las regiones subtropicales de América del Sur en relación con la variabilidad climática. Ph.D. thesis, Universidad Nacional de Córdoba, Córdoba, Argentina.

Francou, B., Vuille, M., Wagnon, P., Mendoza, J., and Sicart, J. M., 2003: Tropical climate change recorded by a glacier in the central Andes during the last decades of the twentieth century: Chacaltaya, Bolivia, $16^{\circ}$ S. Journal of Geophysical Research, 108: 4154, http:// dx.doi.org/10.1029/2002JD002959.

Fraser, R. H., Olthof, I., Carrière, M., Deschamps, A., and Pouliot, D., 2011: Detecting long-term changes to vegetation in northern Canada using the Landsat satellite image archive. Environmental Research Letters, 6: 1-9.

Garreaud, R., 1999: Multiscale analysis of summertime precipitation over the central Andes. American Meteorological Society, 127: 901-919.

Garreaud, R., and Aceituno, P., 2001: Interannual rainfall variability over the South American Altiplano. Journal of Climate, 14: $2779-2789$.

Garreaud, R., Vuille, M., and Clement, C., 2003: The climate of the Altiplano: observed current conditions and past changes mechanisms. Palaeogeography, Palaeoclimatology, Palaeoecology, 3054: $1-18$.

Gil Montero, R., and Villalba, R., 2005: Tree rings as a surrogate for economic stress-An example from the Puna of Jujuy, Argentina in the 19th century. Dendrochronologia, 22: 141-147.

Holmes, R. L., 1983: Computer-assisted quality control in tree-ring dating and measurements. Tree-Ring Bulletin, 43: 69-75.

Hsu, C. W., Chang, C. C., and Lin, C. J., 2007: A practical guide to support vector classification. National Taiwan University. http:// ntu.csie.org/ cjlin/papers/guide/guide.pdf.

Huete, A., Didan, K., Miura, T., Rodriguez, E. P., Gao, X., and Ferreira, L. G., 2002: Overview of the radiometric and biophysical performance of the MODIS vegetation indices. Remote Sensing of Environment, 83: 195-213.

Jönsson, P., and Eklundh, L., 2004: TIMESAT —A program for analyzing time-series of satellite sensor data. Computers and Geosciences, 30: $833-845$.
Kessler, M., 1995: The genus Polylepis (Rosaceae) in Bolivia. Candollea, 50: $172 \mathrm{pp}$.

Landres, P. B., Morgan, P., and Swanson, F. J., 1999: Overview of the use of the natural variability concepts in managing ecological systems. Ecological Applications, 9: 1179-1188.

Lenters, J. D., and Cook, K. H., 1997: On the origin of the Bolivian High and related circulation features of the South American climate. Journal of Atmospheric Sciences, 54: 656-677.

Lenters, J. D., and Cook, K. H., 1999: Summertime precipitation variability over South America: role of the large-scale circulation. Monthly Weather Review, 127: 409-431.

Li, J., Xie, S. P., Cook, E. R., Huang, G., D’Arrigo, R., Liu, F., Ma, J., and Zheng, X. T., 2011: Interdecadal modulation of El Niño amplitude during the past millennium. Nature Climate Change, 1: 114-118.

Lupo, L, Morales, M., Yacobaccio, H. D., Maldonado, A., and Grossjean, M., 2007: Cambios ambientales en la Puna jujeña durante los últimos 1200 años: explorando su impacto en la economía pastoril. Actas XVI Congreso Nacional de Arqueología Argentina Tomo III, Ediciones UNJu, 151-156.

Morales, M. M., Villalba, R., Grau, H. R., and Paolini, L., 2004: Rainfall-controlled tree growth in high-elevation subtropical treelines. Ecology, 85: 3080-3089.

Morales, M. S., Christie, D. A., Villalba, R., Argollo, J., Pacajes, J., Silva, J. S., Alvarez, C. A., Llancabure, J. C., and Soliz, C., 2012: Precipitation changes in the South American Altiplano since 1300 $\mathrm{AD}$ reconstructed by tree-rings. Climate of the Past, 8: 653-666.

Moreau, S., Bosseno, R., Fa Gu, X., and Baret, F., 2003: Assessing the biomass dynamics of Andean bofedal and totora high-protein wetland grasses from NOAA/AVHRR. Remote Sensing of Environment, 15: 516-529.

Ramirez, E., Francou, B., Ribstein, P., Desclottres, M., Guerin, R., Mendoza, J., Gallaire, R., Pouyaud, B., and Jordan, E., 2001: Small glaciers disappearing in the tropical Andes. A case study in Bolivia: Glacier Chacaltaya $\left(16^{\circ} \mathrm{S}\right)$. Journal of Glaciology, 47: 187-194.

Robinson, J., and Evans, R., 1980: A microcomputer-based tree-ring measuring system. Tree-Ring Bulletin, 40: 59-65.

Running, S. W., Nemani, R. R., Heinsch, F. A., Zhao, M., Reeves, M., and Hashimoto, H., 2004: A continuous satellite-derived measure of global terrestrial primary production. BioScience, 6: 547-560.

Schulman, E., 1956: Dendroclimatic Change in Semiarid America. Tucson: University of Arizona Press.

Schweingruber, F. H., 1996: Tree Rings and Environment Dendroecology. Bern: Paul Haupt, 609 pp.

Solíz, C., Villalba, R., Argollo, J., Morales, M. S., Christie, D. A., Moya, J., and Pacajes, J., 2009: Spatio-temporal variations in Polylepis tarapacana annual growth across the Bolivian Altiplano (17-23ㅇ․ Palaeogeography, Palaeoclimatology, Palaeoecology, 181: 296-308

Squeo, F. A., Warner, B. G., Aravena, R., and Spinoza, D., 2006: Bofedales: high altitude peatlands of central Andes. Revista Chilena de Historia Natural, 79: 245-255.

Srur, A. M., Villalba, R., and Baldi, G., 2011: Variations in Anarthrophyllum rigidum radial growth, NDVI and ecosystem productivity in the Patagonian shrubby steppes. Plant Ecology, 212: 1841-1854.

Stokes, M. A., and Smiley, T. L., 1968: An Introduction to Tree Ring Dating. Chicago: University of Chicago Press, 73 pp.

Tan, B., Morisette, J. T., Wolfe, R. E., Gregory, F. G., Ederer, A., Nightingale, J., and Pedelty, J. A., 2011: An enhanced TIMESAT algorithm for estimating vegetation phenology metrics from MODIS data. IEEE Journal of Selected Topics in Applied Earth Observations and Remote Sensing, 4: 361-371.

Trenberth, K. E., 1997: The definition of El Niño. Bulletin of the American Meteorological Society, 78: 2771-2777.

Trenberth, K. E., and Caron, J. M., 2000: The Southern Oscillation revisited: sea level pressures, surface temperatures and precipitation. Journal of Climate, 13: 4358-4365.

Urrutia, R., and Vuille, M., 2009: Climate change projections for the 
tropical Andes using a regional climate model: temperature and precipitation simulations for the end of the 21st century. Journal of Geophysical Research, 114: 15 pp., http://dx.doi.org/10.1029/ 2008JD011021.

Vuille, M., 1999: Atmospheric circulation over the Bolivian Altiplano during dry and wet periods and extreme phases of the Southern Oscillation. International Journal of Climatology, 19: 1579-1600.

Vuille, M., and Bradley, R., 2000: Mean annual temperature trends and their vertical structure in the tropical Andes. Geophysical Research Letters, 27: 3885-3888.

Vuille, M., and Keimig, F., 2004: Interannual variability of summertime convective cloudiness and precipitation in the central Andes derived from ISCCP-B3 data. Journal of Climate, 17: 3334-3348.

Vuille, M., Bradley, R. S., and Keimig, F., 2000: Interannual climate variability in the central Andes and its relation to tropical Pacific and Atlantic forcing. Journal of Geophysical Research, 105: $12,447-12,460$

Vuille, M., Bradley, R., Werner, M., and Keimig, F., 2003: 20th century climate change in the tropical Andes: observations and model results. Climate Change, 59: 75-99.

Vuille, M., Francou, B., Wagnon, P., Juen, I., Kaser, G., Mark, B., and Bradley, R., 2008: Climate change and tropical Andean glaciers: past, present and future. Earth-Science Review, 89: 79-96.

Wang, J., Rich, P. M., Price, K. P., and Kettle, W. D., 2004: Relations between NDVI and tree productivity in the central Great Plains. International Journal of Remote Sensing, 25: 3127-3138.

Wong, C., and Iverson, K., 2004: Range of natural variability: applying the concept to forest management in central British Columbia. Journal of Ecosystems and Management, 4: 1-14.

MS accepted February 2013 